Notes on recent elections

\title{
Election note on the 2013 Norwegian election
}

\author{
Endre Storli \\ University of Essex, UK
}

\section{A R T I C L E I N F O}

\section{Article history:}

Received 20 January 2014

Received in revised form 24 December 2014

Accepted 24 December 2014

Available online $\mathrm{xxxx}$

\section{The 2013 Norwegian general elections}

On September 9th, 2013, Norway held a general election to elect a parliament that would sit between 2013 and 2017. At the time of the election Norway was lead by a Red-Green coalition government that had been in power since the 2005 parliamentary elections. The parties in the coalition were the Labour Party (AP), the Centre Party (SP) and the Socialist Left Party (SV). In an attempt to avoid another defeat, opposition parties joined forces and, for the first time ever, the Progress Party (FrP) was in a real position to join a governing coalition. All the three other centre-right parties (the Conservatives $(\mathrm{H})$, the Christian Democratic Party (KrF) and the Liberal Party (V)) acknowledged it as a possible partner. This proved to be a good strategy for them as the post-election government consisted of the Conservatives and the Progress Party and with the Liberal Party and the Christian Democratic Party as supporting parties in the parliament. ${ }^{1}$

\section{Background and campaign polls}

The Red-Green coalition had been in government with a majority coalition since the 2005 elections. The incumbent coalition kept the unemployment rate low and the inflation rate stable during tough economic times worldwide. At the time of the election the unemployment rate in Norway was

E-mail address: estorl@essex.co.uk.

1 Store Norske Leksikon (Norwegian Lexicon): "Norges Politiske System".
$3.5 \%$ and $8 \%$ in Norway's neighbouring (and often compatible) country Sweden. ${ }^{2}$ As well as maintaining economic stability, the Red-Green coalition passed significant pieces of legislation while in power including equal rights for LGBT marriages and straight marriages (for example in the matter of adoption $)^{3}$ and the postponement of the search for petroleum in the north of Norway (Lofoten, Vesterålen and Senja). ${ }^{4}$ However, critics still chastised the Government for low legislative productivity.

In opposition the Progress Party presented a more moderate public face that allowed it to become a more viable party for cooperation with the Liberal and Christian Democratic parties. The Party's change of leadership in 2006 from Carl I. Hagen to the more moderate Siv Jensen was a reason why the Progress Party became more viable and moderate since 2006. Specifically, the new leader helped the party shed its image as a one that was racist and economically irresponsible, and Progress Party politicians viewed as having more "extreme" opinions lost influence in the party. On the other hand the Liberal Party and the Christian Democratic Party were blamed for the loss in 2009 because of the lack of willingness to work with the Progress Party, and this caused them to be more cooperative in the 2013 campaign.

In most polls before the election the Conservative Party and their possible alliance partners were bettering the parties in the Red-Green alliance. The Conservatives often

\footnotetext{
${ }^{2}$ Statics Norway (Statistisk Sentralbyrå): "Arbeidskraftundersøkinga, sesongjusterte månadsvise tal, november 2013".

${ }^{3}$ Lovdata.no: "Ekteskapsloven".

4 Tv2: "Miljøbevegelsen: En stor seier for miljøkampen".
} 
polled as the strongest party, gathering support from more than 30 percent of the electorate. Much of this support appeared to come from voters who once backed Progress or Labour and were demanding change. Although (or perhaps because) it took more moderate positions, the only right wing party that struggled in the polls in comparison to their 2009 results was Progress, possibly because some voters perceived this election to be a choice between the Conservatives and Labour.

Pre-election polling made prospects for the Red-Green coalition look bad. Support for the Labour Party declined substantially, and the Socialist Left Party and the Centre Party periodically were polling below the threshold of four percent. The Centre Party leader, Liv Signe Navarsete, was highly unpopular and had a habit of lashing out at the electorate and party faithful; she yelled at a voter in a public event for "not knowing what she was talking about", and also yelled at the youth party leader for being "disloyal." The Green Party, not tied to either of the alliances, picked up support from the weak parties of the Red-Green alliance and scored as high as 6.5 percent in some polls. ${ }^{5}$ In particular, unhappy "environmental" voters changed allegiance from the Socialist Left Party to the Greens because many perceived the Left as losing many environmental battles in the coalition.

\section{Electoral system}

The Norwegian electoral system is a proportional representation list system, with 19 geographically decided constituencies and 169 seats in the Storting (the Norwegian Parliament). Elections are held every 4 years and all seats are up for election at the same time. Regional party branches rank their candidates in lists, and all mandates are elected from these lists. This means that Norwegians vote more for parties and less for candidates. There is a $4 \%$ threshold, and parties obtaining a vote under this threshold only are eligible for direct mandates in the different constituencies, and not the levelling mandates designed to ensure the amount of seats in Parliament equals the percentage of vote received. The electoral system makes one party majorities unusual and coalition governments are the norm.

\section{Parties, coalitions and the campaign}

In the Norwegian election in 2013 there were three different coalition alternatives that had a realistic possibility of forming the new government. They were the sitting Red-Green alliance (Labour, the Centre Party and the Socialist Left Party), a Blue-Blue alliance (the Conservatives and the Progress Party) or a Blue-Green alliance (the Conservatives with the Christian Democratic Party, the Liberal Party or both, and possibly the Progress Party). There are nine parties that realistically contest seats in the Norwegian parliament; the Conservative Party (Høyre $-\mathrm{H}$ ), the Progress Party (Fremskritspartiet - FrP), The Christian

\footnotetext{
5 PollofPolls: "Gjennomsnitt av nasjonale meningsmålinger om stortingsvalg".
}

Democratic Party (Kristelig Folkeparti - KrF), the Liberal Party (Venstre - V), the Labour Party (Arbeiderpartiet AP), the Socialist Left Party (Sosialistisk Venstreparti - SV), the Centre Party (Senterpartiet - SP), the Green Party (Miljøpartiet De Grønne - MDG) and Red (Rødt - R). The two main (and only two realistic) contenders for the Prime Minister position were the Labour Party incumbent Jens Stoltenberg and the Conservative leader Erna Solberg.

Two of the most important campaign events were the party leader debates hosted by the two largest TV-channels in Norway, NRKs and Tv2s. The leaders of the above nine parties, each of which were polling more than 1 percent in the polls partook in the event. NRKs' party leader debate had 600000 viewers, a size equal to approximately about one fourth of the electorate, and 340000 watched the debate on Tv2. ${ }^{6}$ In the party leader debates the focus often centred around the issues of healthcare, the environment, "life after oil in Norway" and the possible coalitions after the election. ${ }^{7}$ The largest newspapers declared the Liberal Party Leader Jens Stoltenberg the winner of the first debate and Conservative Leader Erna Solberg victorious in the second.

The two issues of the environment and the state of the economy after the oil boom worked to the advantage of the Green Party. The Party was polling only 6.5 percent before the discussion but subsequently gained its first ever parliamentary mandate in Oslo through the direct vote. ${ }^{8}$ An issue the environmental lobby put onto the agenda was that the former "environmental" party, the Socialist Left Party, failed to make a positive impact on the environmental policies whilst in government, and that the Liberal Party, which was the spokesmen for green policies on the right side of the scale, had lost almost all influence due to falling below the four percent threshold.

The other big issue in the 2013 elections was the possible coalition outcomes after the votes were counted; the Red-Green incumbent coalition accused the opposition of being unable to make up their minds and cooperate, suggesting that they would not be able to come together to form a stable majority coalition. They pointed to the fact that in the wake of the 2009 election, both the Liberal Party and the Christian Democratic Party refused to cooperate with the Progress Party and the Progress Party refused to support a government it could not join. Even in the 2013 elections neither the Christian Democratic Party nor the Liberal Party would promise to cooperate with the Progress Party and this raised confusion as to what would constitute a viable alternative to the Red Green Coalition. The RedGreen Alliance made a point that the Progress Party had a history of being perceived as economically irresponsible, an argument fronted by all the other parties in former elections as well. But this the opposition alliance (Blue-Blue and Blue-Green) countered by arguing that the election result would be important in the post-election negotiations

\footnotetext{
6 Aftenposten: "Dobbelt så mange så NRKs partilederdebatt”.

7 Norsk Rikskringkasting: “- Flere brutte løfter som er blitt gjentatt i valgkampen".

${ }^{8}$ Nevertheless, the party did fall below the $4 \%$ necessary for a levelling mandate.
} 
Table 1

The Norwegian parliamentary election $2013^{\mathrm{a}}$

\begin{tabular}{|c|c|c|c|}
\hline Party & Amount of votes: & $\begin{array}{l}\% \text { Of the vote (change in } \\
\text { percentage points since } 2009 \text { ) }\end{array}$ & $\begin{array}{l}\text { Seats in Parliament } \\
\text { (change since 2009) }\end{array}$ \\
\hline Labour Party (AP) & 874769 & $30,8(-4,5)$ & $55(-9)$ \\
\hline The Conservatives $(\mathrm{H})$ & 760232 & $26,8(+9,6)$ & $48(+18)$ \\
\hline The Progress Party (FrP) & 463560 & $16,3(-6,6)$ & $29(-12)$ \\
\hline The Christian Democratic Party (KrF) & 158475 & $5,6(0,0)$ & $10(-)$ \\
\hline The Centre Party (SP) & 155357 & $5,5(-0,7)$ & $10(-1)$ \\
\hline The Liberal Party (V) & 148275 & $5,2(+1,4)$ & $9(+7)$ \\
\hline Socialist Left Party (SV) & 116021 & $4,1(-2,1)$ & $7(-4)$ \\
\hline The Green Party (MDG) & 79152 & $2,8(+2,4)$ & $1(+1)$ \\
\hline Red (R) & 30751 & $1,1(-0,3)$ & $0(-)$ \\
\hline Others & 49437 & $1,6(+0,6)$ & $0(-)$ \\
\hline Turnout: $78,2 \%$ & Invalid Votes: 3255 & & Blank Votes: 12874 \\
\hline The Red-Green Alliance & 1146147 & $40,4(-7,3)$ & $72(-14)$ \\
\hline The Blue-Blue Alliance $(+\mathrm{KrF}$ and $\mathrm{V})$ & 1530542 & $53,9(+4,5)$ & $96(+13)$ \\
\hline Others $^{\mathrm{b}}(+$ MDG and $\mathrm{R})$ & 159340 & $5,5(+2,7)$ & $1(+1)$ \\
\hline
\end{tabular}

a Regjeringen (The Norwegian Government): “Kommunal og Moderniseringsdepartementet: Landsoversikt - Stortingsvalget”.

b Note: The Green Party and Red did not express allegiance to any of the two possible alliances and is therefor included in the "others" column instead of any alliance.

and that the different parties' vote share would impact each party's influence on the policy, and which parties would sit in the government., 9,10

Ultimately, the Conservative Party's willingness to lead and cooperate with all centre and right wing parties was viewed as one of the main reasons why it had such a successful election.

\section{Results}

The results of the election are presented in Table 1, which shows the big loss suffered by the Red-Green coalition. When ballots were counted, it had 14 less seats and suffered a $7.3 \%$ decline in votes. Another party that suffered was Progress, which, despite its moderation, lost 12 seats and saw its vote share decline by 6.6 percent. The "winners" of the elections were the Conservatives and Liberals. The former party gained 18 seats and $9.6 \%$ of the vote and the latter party saw its vote share increase by $1.4 \%$ in comparison to 2009. This enabled the Liberals to eclipse the four percent threshold and seven of its members were sent to Parliament. Although not part of an alliance, the Green Party gained its first ever seat in the Norwegian Parliament and captured2.4 percent of the vote. The Conservative Party's and the Liberal Party's increased vote share made the election result centre-right skewed. ${ }^{11}$

Although their vote share was lower than suggested by the pre-election polls, the election still resulted in a "Blue-Blue" win.

Turnout in the election was the highest reported for Norway since $1997-78.2 \%$ of eligible citizens went to the polls and 2836029 votes were cast. ${ }^{12}$ Turnout among younger voters improved significantly in comparison to the last two elections, and the level of early voting, at $30.2 \%$,

\footnotetext{
${ }^{9}$ E24: "Stoltenberg: Frp har gjort seg skyldig i en gedigen valgbløff".

10 Dagbladet: “- Venstre eller KrF havner på vippen etter valget”.

11 Table 1: Regjeringen (The Norwegian Government): "Kommunal og Moderniseringsdepartementet: Landsoversikt - Stortingsvalget".

12 Statics Norway (Statistisk Sentralbyrå): "Stortingsvalet, 2013".
}

reached a record high. ${ }^{13}$ Some communities experimented with electronic voting, and this, too, resulted in higher turnout levels. It remains to be seen whether Parliament will approve of e-voting nationwide in time for the next election. ${ }^{14,15}$

\section{Implications}

The election results and the post-election negotiations had the Conservative Party and the Progress Party forming a minority government, supported in parliament by the Christian Democratic Party and the Liberal Party. The vote and seat share of the government and the supporting parties eclipsed fifty percent. The coalition government (the Conservatives and the Progress Party) obtained 77 seats and only need support from either the Liberals (nine seats) or the Christian Democrats (ten seats) to reach a majority (85 seats) in parliament. ${ }^{16}$

There are tensions between the two governing parties in the areas of economic policy. More specifically, the Conservatives support toll roads while Progress remains opposed to the idea. The Liberals and Christian Democrats disagree with the Government over their positions on asylum and the environment. ${ }^{17}$ These two policy fields likely are the reason why the Liberal Party and the Christian Democratic Party did not formally enter the Coalition. On the other hand there is wide agreement across the four parties on reducing taxation, arming the police and having less restrictive labour laws. ${ }^{18}$

The opposition alliance, the Red-Greens, dissolved as a result of the election and both the Centre Party and the

\footnotetext{
13 Statics Norway (Statistisk Sentralbyrå): "Stortingsvalet, 2013".

14 Regjeringen (The Norwegian Government): "Forsøk med stemmegivning over internett".

15 Norsk Rikskringkasting: "Høyere valgdeltakelse blandt unge".

16 Regjeringen (The Norwegian Government): "Kommunal og Moderniseringsdepartementet: Landsoversikt - Stortingsvalget”.

17 Verdens Gang: "Dette skal Frp og Høyre slåss om".

18 Nettavisen: "Regjeringsplattformen: Her er Erna og Sivs Løfter".
} 
Socialist Left Party have discussed a change in leadership. The Socialist Left Party is considering merging with the Green Party, Red or both. Although the alliance officially has dissolved, all three parties have stated that they could possibly work together in parliament and run together in the 2017 elections.

The post-election leaves Norway with a new minority Blue-Blue coalition government supported by the Christian Democratic Party and the Liberal Party. A Green Party member sits in Parliament for the first time and Erna Solberg became only the second ever female Prime Minister in Norway (the only other being Gro Harlem Brundtland from the Labour Party). Another significant outcome from this election was that the Progress Party did, for the first time ever, take part in the Government. Prime Minister Erna Solberg has expressed hope that the Liberal Party and the Christian Democratic Party will eventually enter the cabinet to create a majority Government. ${ }^{19}$

The increased number of parties now contesting elections and winning seats makes minority governments more likely in the future. There is concern that with Progress' moderation and entrance into Government, a new right wing protest movement will emerge.

\section{Sources:}

- Aftenposten: “Dobbelt så mange så NRKs partilederdebatt” 09.09.13 (http:// www.aftenposten.no/kultur/Dobbelt-sa-mange-sa-NRKspartilederdebatt-7304847.html\#.UtTbIXkwGCE)(Downloaded: 13.01.14).

- Dagbladet: “- Venstre eller KrF havner på vippen etter valget” 04.09.13 (http://www.dagbladet.no/2013/09/04/nyheter/norsk_regnesentral/ anders_loland/clara-cecilie_gnther/valg13/29068649/) (Downloaded: 13.01.14).

- E24: “Stoltenberg: Frp har gjort seg skyldig i en gedigen valgbløff” 25.12.13 (http://e24.no/makro-og-politikk/stoltenberg-frp-har-gjort-segskyldig-i-en-gedigen-valgbloeff/22684233) (Downloaded: 13.01.14).

- Lovdata.no: "Ekteskapsloven" (http://lovdata.no/dokument/NL/lov/ 1991-07-04-47) (Downloaded: 11.02.14)

- Nettavisen: "Regjeringsplattformen: Her er Erna og Sivs Løfter" (07.10.13) (http://www.nettavisen.no/politikk/article3691267.ece) (Downloaded: 11.02.14).

- Norsk Rikskringkasting: “- Det er ikke lederegenskapene som skiller Erna og Jens” 16.08.13 (http://www.nrk.no/valg2013/_-ikkelederegenskapene-som-skiller-1.11185497) (Downloaded: 13.01.14).
- Norsk Rikskringkasting: “- Flere brutte løfter som er blitt gjentatt i valgkampen" $\quad 05.09 .13 \quad$ (http://www.nrk.no/valg2013/slik-blirpartilederdebatten-1.11218489) (Downloaded: 13.01.14).

- Norsk Rikskringkasting: "Høyere valgdeltakelse blandt unge" (18.12.13) http://www.nrk.no/norge/hoyere-valgdeltakelse-blant-ungdom-1. 11424535 (Downloaded: 10.02.14).

- Norsk Rikskringkasting: “Jens tar inpå Erna” (18.08.13) (http://www.nrk. no/valg2013/jens-tar-innpa-erna-1.11187235)(Downloaded: 11.02.14).

- PollofPolls: "Gjennomsnitt av nasjonale meningsmålinger om stortingsvalg" (http://www.pollofpolls.no/?cmd=Stortinget\&do=visallesnitt) (Downloaded: 13.01.14).

- Statics Norway (Statistisk Sentralbyrå): “Arbeidskraftundersøkinga, sesongjusterte månadsvise tal, november 2013" 26.01 .14 (http:/ www.ssb.no/arbeid-og-lonn/statistikker/akumnd/maaned/2014-0129\#content) (Downloaded: 11.02.14).

- Statics Norway (Statistisk Sentralbyrå): “Stortingsvalet, 2013” 18.12 .13 (http://www.ssb.no/stortingsvalg/hvert-4-aar?

fane $=$ tabell $\&$ sort $=$ nummer \&tabell=154801) (Downloaded: 13.01.14).

- Statics Norway (Statistisk Sentralbyrå): “Stortingsvalet, 2013: Rekordmangen forhåndsrøystar" $18.12 .13 \quad$ (http://www.ssb.no/valg/ statistikker/stortingsvalg/hvert-4-aar/2013-10-29\#content) (Downloaded: 13.01.14).

- Store Norske Leksikon (Norwegian Lexicon): "Norges Politiske System” (http://snl.no/Norges_politiske_system) (Downloaded: 13.01.14).

- Regjeringen (The Norwegian Government): "Forsøk med stemmegivning over internett" (http://www.regjeringen.no/nb/dep/kmd/ kampanjer/valg/valg/stortingsvalg13/forsok-med-stemmegivningvia-internett.html?id=729202) (Downloaded: 11.02.14).

- Regjeringen (The Norwegian Government): “Kommunal og Moderniseringsdepartementet: Landsoversikt - Stortingsvalget” 07.10.13 (http://www.valgresultat.no/bs5.html) (Downloaded: 13.01.14).

- Regjeringen (The Norwegian Government): “Norske Regjeringer siden 1945” (http://www.regjeringen.no/nb/om_regjeringen/tidligere/ oversikt/ministerier_regjeringer/nyere_tid/regjeringer.html? $\mathrm{id}=438715$ ) (Downloaded: 04.02.14).

- Tv2: “Miljøbevegelsen: En stor seier for miljøkampen” Verdens Gang: "De grønne kaprer taktiske stemmer" 08.09.13 (http://www.vg.no/ nyheter/innenriks/valg-2013/artikkel.php?artid=10151400) (Downloaded: 13.01.14).

- Verdens Gang: "De Grønne lover å felle regjeringen på oljeboring” 06.09.13 (http://www.vg.no/nyheter/innenriks/valg-2013/artikkel. php?artid=10143373) (Downloaded: 13.01.14).

- Verdens Gang: “Dette skal Frp og Høyre slåss om” 01.10 .13 (http:/ www.vg.no/nyheter/innenriks/norsk-politikk/artikkel.php? artid=10152338) (Downloaded: 13.01.14).

- Verdens Gang: “Høyre og FrP går I Regjering Sammen” 10.09.13 (http:// www.vg.no/nyheter/innenriks/norsk-politikk/artikkel.php? artid=10152286) (Downloaded: 13.01.14).

- (11.03.11) (http://www.tv2.no/nyheter/innenriks/miljoebevegelsen-enstor-seier-for-miljoekampen-3439624.html\#.Uvmo_nkwGCE) (Downloaded: 11.02.14).

19 Verdens Gang: “Høyre og FrP går I Regjering Sammen”. 